\title{
Appropriation of ICT in the educational field: approach to public policy in Colombia years 2000-2019
}

\author{
Diego Fernando Barragán Giraldo \\ dibarragan@unisalle.edu.co \\ Universidad de La Salle, Bogotá, Colombia \\ Juan Carlos Amador Báquiro \\ jcamadorb@udistrital.edu.co \\ Universidad Distrital Francisco José de Caldas, Bogotá, Colombia
}

\begin{abstract}
Summary
This work document presents an approach to the appropriation of Colombian public policy related to the ICTs in the educational field, during the period of 2000 thru 2019. After a walkthrough to the scenario of international initiatives for the implementation of ICTs in schools, some theoretical approaches are presented that configure what in this work has been named the field of digital appropriation in education, which oriented the analysis of data. Subsequently, the analytical results of the public policy milestone documents during the aforementioned period are presented; as well as the testimonies of stakeholders, showing an underlying instrumental digital literacy logic, subordinated to the market, that does not seem to allow the generation of digital culture from the school. Amongst other aspects, it is concluded that, despite the investment made in connectivity and equipment provisioning, public policy has not transformed the practices of educational actors.
\end{abstract}

\section{Keywords}

Public policy; Colombia; Information and Communications Technologies; appropriation; field. 


\section{Introduction}

Colombian public policy has tried to articulate itself to international demands for the last three decades; in such a way that it has assumed global logic regarding economic and social issues that impact various aspects of daily life. In the educational field, the same thing has happened, because if learning outcomes must be improved (OECD - Organization for Economic Cooperation and Development, 2017), the corresponding governments must implement various strategies at the different levels of educational training, which respond to the challenges of the so called information and knowledge society, as well as the commitments undertaken by Colombia after the long process to be accepted, in 2018, as a member of the Organization for Economic Cooperation and Development (OECD).

Thus, the confidence to promote the process of acquisition of digital skills in citizens continues to be configured as a directive in education, particularly in the development of strategies that contribute to digital literacy, articulated to the insertion in the labor market (UNESCO - United Nations Educational, Scientific and Cultural Organization, 2019; 2017; 2016; 2014b), which in the Colombian case has been evident, such as in the document that establishes several recommendations to improve the digital transformation of the country, an issue that will determine the course to follow as a nation (OECD, 2019).

It is in this context, that this work will approach Colombian public policy regarding ICTs ${ }^{1}$ in its appropriation of the educational field (preschool, basic and secondary), relying on the theoretical construct field of digital appropriation in education, which allows to glimpse at some relevant tensions, since public policy deserves to be viewed at critically.

\section{Some Background}

Since the end of last century, governments have designed and implemented public policies to undertake ICTs in education. Since the 1980s, several countries have been interested in introducing computers in schools, in order to encourage in their students skills to enter into the labor market. In England, for example, since 1981, the program called Microcomputers for Schools emerged, under the responsibility of the Ministry of Commerce and Industry, while in the United States, in the middle of that same decade, school computer laboratories were introduced with the aim of promoting technological skills (DfES, 2003). In the case of Latin America, Brazil explored for the first time, around 1985, the implementation of pilot projects of educational computers in public schools, influenced by the so-called educational technology (Quartiero, Bonilla, \& Fantin, 2012).

During the 1990s, the massive spread of microcomputers and the novelty of the Internet meant that, in addition to the technical approach, the pedagogical component was introduced in a more explicit way. At the beginning of this decade, England incorporated this topic into the Ministry of Education and Sciences, which launched the "New Technologies for Better Schools" program. Canada also designed an educational portal with digital contents for teachers and students called 'Schoolnet'; which was aimed to connect the Internet to schools and offer curricular alternatives (McMillan, Honey, \& Mandinac, 2003). At the same time, New Zealand introduced a computers and Internet program in schools through the strengthening of infrastructure and encouraging technical skills; while in Ireland, given its experience in designing and exporting software, equipped schools with computers and provided technical assistance to teachers. For its part, the United States

\footnotetext{
1 In this article, Information and Communication Technologies (ICTs) refer to fixed and mobile digital technologies, in their reticular and interactive nature, as well as their Internet connection (Amador, 2018).
} 
promoted the use of ICTs in schools as a basis for achieving curricular transformations, using resources such as multimedia, simulators, and educational software (Quiroga, 2008) ${ }^{2}$.

In the first and second decades of 2000, with the penetration of the Internet in most countries around the world, but also with the gaps related to access to this resource, especially in historically lagging regions, public policies were oriented to invest in the introduction of ICTs in school, not only as a possibility of transforming the curriculum, but also as a way of adapting the school institutions to the challenges of the so called information society. As an example, New Zealand assumed the incorporation of ICT in schools as a strategy to reform the educational system in a structural way, based on alliances with communities and companies (Quiroga, 2008). South Korea, from the Ministry of Education, Sciences and Technology, has promoted a standard of good practices in the use of ICTs, provided with computers and Internet to public schools, promoted the development of quality contents for the educational system and promoted teacher training policies. For its part, Canada expanded its technological infrastructure, introduced guidelines for the development of skills in the use of ICTs, and promoted the design of digital contents for academic areas $^{3}$.

In the Latin American setting, the experiences have been heterogeneous, but they also contain common aspects. In several reports (OECD, 2005) (UNESCO, 2002), it is stated that public policies in the region have contributed to reducing gaps compared to developed countries, by expanding equipment coverage, expanding the Internet in schools, producing educational contents and optimizing the conditions of technological infrastructure. Countries such as Brazil, Mexico, Argentina, Chile, Costa Rica and Uruguay have been pioneers in the design and implementation of policies to expand coverage, as well as increase Internet penetration in educational institutions. For example, while in the early 2000s most countries had an average of 100 students per computer, with the exception of Costa Rica and Chile, which had an average of 60, and while at the end of this decade this ratio began to decrease to less than 50 computers per student, in recent years this outlook has changed radically. Thus, there are different reasons why some countries have reached, after 2010, less than 10 students per computer (Agencia Española de Cooperación Internacional para el Desarrollo, 2011).

One of these reasons is the implementation of the 1 to 1 model. This model consists of the distribution of laptops or tablets to students and teachers, so that they have personalized access to ICTs and develop skills for knowledge management. Implemented since the 1990 s and based on the proposals by Negroponte and Papert (cited by Jara, 2014), who proposed the use of low-cost laptops to be used in educational systems of emerging countries, the aforementioned model originated in United States and Australia (with funding from municipal governments and parents' school associations). Thus, interaction, collaborative work and network participation would be encouraged; by 2015, the financing of this model in several Latin American countries reached US\$ $43,050,000$ (World Bank, 2006). In this regard, 1 to 1 experiences from various countries in the region can be identified (Agencia Española de Cooperación Internacional para el Desarrollo, 2011) ${ }^{4}$.

\footnotetext{
2 In the European context, an organization of educational portals that integrated ministries of education from 28 countries was created, in order to stimulate collaboration between schools and governments (EUN, 2007). In Latin America, around this same decade, in view of the deregulation of the telecommunications industry, the Chilean government declared that this country would become a digitized nation through an educational computers program called Links (McMillan, Honey, \& Mandinac, 2003) (Quiroga, 2008).

3 While the United States, based on the permanent evaluation of the impact of ICTs in schools, maintained its investment policy in these programs, England emphasized its support to ICTs use policies, especially the Internet, as a strategy to optimize both teaching practices in classrooms and management practices at the educational institution (McMillan, Honey, \& Mandinac, 2003) (World Bank, 2006) (European Commission , 2006) (OECD, 2005).

4 Before the implementation of 1 to 1 programs, a series of initiatives developed in various countries of the region are highlighted. As an example, Costa Rica stands out, a pioneer in starting from this decade an ICT policy for schools through the use of the Logo language, aimed at developing logical thinking and creativity
} 
In the first place, Uruguay, as a pioneer of the 1 to 1 model in the region through the 'Ceibal' (Basic Educational Connectivity Computing for Online Learning) program, began its implementation in 2006, expanded its coverage to basic education levels and Secondary, it reached 670,000 computers in 2015 and trained 26,000 teachers. In second place, Argentina, from the 'Equality Connection' program, which began to be implemented since 2010, it reached 3 million computers in 2015 and implemented the model in secondary schools, special schools and teacher training institutes. Third, place Chile, through the program called Computational Mobile Laboratories (LMC), reached 250,000 students benefited only in the fourth and fifth grades of primary education. In fourth place, Brazil, through the UCA project 'Um computador por aluno' (PROUCA), implemented since 2010, it reached 37 million students at the primary and secondary levels. ${ }^{5}$

Lastly, Colombia, through the program called Pilot 1 to 1 , introduced in a first stage (2008-2011) 1,500 restored portable computers in some municipalities, and strengthened the "Computers to Educate" program (proposed since 1999 in the Conpes - National Council for Economic and Social Policy document No. 3063), reaching a national average of 7 students per computer in 2014 and 4 students per terminal in 2017 (Luna, 2018). The case of Colombia will be explained in greater detail in the results section.

The previous outlook, both in the international and Latin American settings, shows two major issues for debate. The first, has to do with the rationalities that guide the introduction of ICTs in schools, in which three directives can be distinguished in this regard: the economic, the social and the educational. Economic rationality proposes that ICTs are essential in school since they are the basis for students to develop skills and competencies aimed at entering the labor market, promote the growth of companies and, thus, contribute to the dynamics of the global economy. Social rationality proposes that ICTs are an instrument of social inclusion and that their massification constitutes a useful strategy to reduce gaps, not only those related to lack of access, but also those associated with forms of discrimination by social class, gender, ethnicity and age. Finally, educational rationality proposes that education communities should not only take advantage of ICTs to modernize the school, optimize educational practices and promote improvements in school management, but also introduce structural educational reforms that contribute to transition from transmission and banking pedagogies to interactive and dialogical pedagogies that contribute to the development of students thinking, in tune with the conditions of the information and knowledge society.

And the second issue of discussion refers to the challenges that pedagogy must face, understood as a field of knowledge over education, facing the processes of digital access, digital literacy and technological appropriation. In other words, it is about building criteria and mediations that contribute to overcoming the instrumental, modernizing and economical nature of the incorporation

skills (Redal, 2005). Chile, as already mentioned, through the Links program, around this time, promoted the interconnection of schools through the Internet, while promoting virtual spaces for collaboration and promoted the design of digital contents to support the curriculum transversally (Hepp, 2003). For their part, Brazil, from its ProInfo program, and Mexico through the Schools Network program, agreed on using ICTs as transversal elements to the curriculum. Later, in the 2000s, Argentina launched its 'Educate' program, the region's first public national educational portal dedicated to the use of the ICTs in education. During this same decade, the ministers of education of 16 countries in the region formed the Latin American Network of Educational Portals (Relpe) with the purpose of supporting the development of their portals and sharing digital contents (Relpe, 2004). Around this same time, after the penetration of the Internet in several countries in the region, programs of great relevance in this field were launched; for example, 'Encyclopedia' in Mexico, 'Huascarán' in Peru, the Connectivity Plan in Uruguay, Resource Centers of Learning in El Salvador and the National Program of New Technologies in Colombia, amongst others (Jara, 2014).

${ }^{5}$ For its part, El Salvador, in accordance with the objectives of the program Closing the Knowledge Gap, has implemented since 2009 a series of 1 -to-1 strategies with low-income grade school students from remote contexts. Likewise, Costa Rica, a country that introduced the Mobile Technologies program since 2007, reached 25,000 students in 2015 from cycles I and I at the primary level (Agencia Española de Cooperación Internacional para el Desarrollo, 2011) (Quartiero, Bonilla, \& Fantin, 2012). 
of ICTs in schools and developing processes, practices and products in tune with the transformations of digital culture.

\section{Methodology}

This work, of a qualitative nature, aimed to make an approach to the appropriation of the Colombian public policy related to ICTs and digital learning in the educational field during the period 2000-2019, investigating the concepts that underly the state proposals.

The study was carried out in two phases. In the first, an analysis of the documentary corpus of public policy milestone documents was carried out, as follows: a) conformation of the archive, with the following documents: Connectivity Agenda for the year 2000, Ten-year Plan for Education 2006-2016, Sector Plan for Education 2006-2010, National Plan for Information and Communications Technologies for 2008, Law 1341 of 2009, "Live Digital" Plan for 2010-2014, "Live Digital" Plan for 2014-2018, TICs Plan, MEN (Ministerio de Educación Nacional) 2014-2018, Tenyear Plan for Education 2016-2026 and the Strategic Plan by Ministry of ICTs 2019-2022, b) structuring and categorical analysis and c) explicitness of the regularities found.

In the second phase, 21 interviews were conducted with education experts and professionals, who due to their vast experience could contribute to understanding the appropriation of public policy at the preschool, basic and middle school levels in urban, rural and difficult to access zones. The inclusion criteria for the experts were a) professors, researchers or managers who knew Colombian educational institutions in situ b) who had more than 10 years of experience in the educational field and c) who had participated in at least one project of National character with the Ministry of Education or the Ministry of ICTs. For education professionals, the criteria were: a) they had to have classroom experience, b) they had to have some innovative proposal for the implementation of ICTs.

The information collected was processed following the main directions of the content analysis; This methodological option allows addressing "the internal structure of communication (composition, organization, dynamics) and the context in which the information is produced" (Galeano, 2009, p. 123), in such a way that the emerging comprehensive structures were accessed in the narrative system (Huberman \& Miles, 1991) (Creswell, 1997), in order to make inferences and establish points of agreement and disagreement. Previous categories were assumed that were synchronously and diachronically strengthened with the development of the analysis of the documentary archive and of the testimonies recovered articulating with the field of digital appropriation in education that is shown in the following section.

\section{Digital Appropriation in the educational field}

The appropriation of any phenomenon refers to practical dimensions. Appropriate, talks about a set of tasks in which various actions of the instrumental, epistemological and axiological order are articulated in which what is appropriate is practiced, "interpreting is always applying", recalls Gadamer (1992, p. 432) and also how the attributes of certain cultural artifacts are used and modified accordingly to the interests and needs of social actors (De Certeau, 2007).

Now then, the approach to the relations between the digital world and its appropriation, necessarily goes through the evolution of proposals such as those of the network society (Castells, 2000; 2003; 2006), liquid society (Bauman, 2000; 2016), cyberculture, collective intelligence, algorithmic 
intelligence, semantic sphere (Lévy, 1997; 2011; 2019), transparency of society (Han, 2015; 2016), post-truth era (Ibáñez, 2017), communicational interfaces (Scolari, 2018), the convergence of media and media culture (Jenkyns, 2006), post-humanism and transhumanism (Hottois, 2013; 2015), digital cultures and digital humanism (Doueihi, 2008; 2011a; 2011b), amongst others.

It is within this context that generating the culture of connectivity, of which Van Dijck (2013) talks about, entails; on the one hand, promoting opportunities in relation to the configuration of forms of social interaction in which complex options of subjectivation take place. But, on the other hand, it invites us to think about the risks of uncritically assuming the technological and cultural demands of the constitution of subjectivities of this type, especially due to the algorithmic bases of society (Van Dijck, 2013, p. 255). It is a set of interactions that produce common experiences in which the human being is recreated and subjected, in relation to the individual type that the work environment demands, which is increasingly developed based on the appropriation of technologies (World Bank , 2019), but at the same time it makes us think about the cost, conditions and possibilities in terms of equality and ecological sustainability (Domingo \& Doménech, 2018) (Chacaltana, Dema, \& Ruiz, 2018).

Similarly, one can talk about digital culture, which stands as a system of practices in which the human being is subjected and has as its own what Doueihi (2008) points out as something fundamental: digital literacy "which is not a simple "numbering" or a set of rules that allow technology to be manipulated. This digital literacy is defining new socio-economic realities, but it is also providing crucial, and even fundamental, modifications to a set of abstractions and concepts that operate on our general social and political horizons" (p. 15). Digital literacy, then appears as the initiatory route to develop the potential of digital culture, which, as already noted, is in no way a movement devoid of hegemonic intentions and tensions of powers.

On the other hand, the International Labor Organization (2019) insists that "today's skills will not coincide with tomorrow's jobs, and the newly acquired skills could quickly become obsolete. If we let the digital economy continue as until now, the regional gap and the gender gap will probably widen further" (p. 18) in such a way, continues the ILO, that a generation of what has been called digital laborers will be configured (Merkel, 2018), thus exacerbating job insecurity, but configuring itself as a horizon of conditions for tomorrow's labor market.

In this way, it stands out how the digital culture and that of connectivity allow us to highlight the need to promote the appropriation of capacities and skills, which allow human beings to be linked to work environments, in order to contribute to processes of socialization and subjectivation of diverse orders such as political, psychological and cultural, for example. Phenomena that, in any case, must be critically reviewed based on their possibilities and limitations where what is understood by humanity is affected (Calvo, 2018).

Thus, education is not intact. The aforementioned is materialized in the growing confidence regarding the possibilities of ICTs, to generate significant learning in students, impacting pedagogical, didactic, curricular and evaluative issues (Barragán, 2013), such as when speaking of ICTs competences (see Table 1 ), but especially on the meaning of education and its relationship with the labor market, to the point of talking about education throughout life (Hagel, Schwartz, Jeff, \& Bersin, 2017), to name just one trend.

\begin{tabular}{|c|l|}
\hline Basic & $\begin{array}{l}\text { Ability to use ICTs in basic tasks and as a learning tool. Can also be referred to } \\
\text { as digital literacy skills. }\end{array}$ \\
\hline Advanced & $\begin{array}{l}\text { Ability to use simple computer tools in general work contexts (jobs not related to } \\
\text { information and communication technologies) }\end{array}$ \\
\hline
\end{tabular}


Professional $\quad$ Ability to use complex computing tools and/or create, develop and renew such tools.

Table 1. Information and communication technologies (ICTs) skills.

Source: Elaboration from Cedefop (2014).

At impacting education, the type of human being wanted to train, it is necessary to rethink about the effectiveness of the prevailing models in which, for several decades, trust has been placed in spaces for interaction with technologies and, more recently, with the digital ones. Here, a genuine field of inquiry occurs.

On the other hand, from Bourdieu's $(2002 ; 1980)$ perspective, when we refer to the field, we make reference to a system of social interactions that is established based on the emerging tensions in multiple spaces: "the fields present themselves to synchronous apprehension as structured spaces of positions (or posts) which properties depend on their position in these spaces, and which can be analyzed independently of the characteristics of their occupants (who are partly determined by the positions) "(Bourdieu, 2002, p. 112). Thus, the field of digital appropriation ${ }^{6}$ is proposed, which refers to a system of practices that promote ways to foster relationships between digital environments and everyday life, in order to generate contextualized learnings and teachings to achieve concrete results, which, depending on the intentions, seek to produce certain types of individuals who demonstrate specific skills, in relation to the established training horizons (see table 2).

\begin{tabular}{|l|l|}
\hline \multicolumn{1}{|c|}{ Dimension } & Configurating Elements \\
\hline & Digital literacy technical skills. \\
& Critical sense of digital culture. \\
& Digital citizenship configuration. \\
& Pedagogical and educational practices that \\
promote digital culture. & Tensions between traditional and digital \\
& education. \\
& Understanding of digital culture in the field of \\
Dispositions (habitus) & education. \\
& Innovative practices. \\
& Legitimation of hegemonic structures of power \\
and understanding of the world. & Resistances or acceptance of the constituted \\
& public policy. \\
& Concrete experiences \\
\hline Players & ICT skills. \\
\hline & Students, trainers, parents, school leaders, \\
\hline
\end{tabular}

${ }^{6}$ This proposal was configured and adjusted as the documents were analyzed and based on the narratives of the various actors. The work of Barragán, Quiroga and Martínez (2018) was taken as a schematic basis. 


\begin{tabular}{|c|c|}
\hline & public policy makers. \\
\hline Game & $\begin{array}{l}\text { The appropriation and resistances of digital } \\
\text { culture aspects in learning and teaching } \\
\text { practices, in relation to constituted public policy. }\end{array}$ \\
\hline Objects at stake & $\begin{array}{l}\text { Understanding of digital culture in the field of } \\
\text { education. } \\
\text { Promises of development in the appropriation of } \\
\text { skills for digital culture. } \\
\text { Digital literacy skills and competences that } \\
\text { enable better learning and teaching processes. } \\
\text { Guarantee of school and social success. } \\
\text { Public policy effectiveness. }\end{array}$ \\
\hline Investments & $\begin{array}{l}\text { Trust in public policy. } \\
\text { Educational innovation. } \\
\text { Digital skills appropriation. } \\
\text { Technological support (machines and networks). } \\
\text { Foundation and image on public policy. } \\
\text { Prospective. }\end{array}$ \\
\hline Capital & $\begin{array}{l}\text { Educational and pedagogical practices. } \\
\text { Notions about digital culture. } \\
\text { Beliefs about public policy. } \\
\text { Body and intellectual dispositions to interact in } \\
\text { the digital culture. } \\
\text { Technological support (machines and networks). } \\
\text { Educational and pedagogical strategies }\end{array}$ \\
\hline
\end{tabular}

Table 2. Configurating elements of the field of digital appropriation in education. ${ }^{7}$

Source: Authors' elaboration.

In this way, digital appropriation in education is crossed by the various interactions that take place in the field that configures it. Thus, individuals can appropriate those elements that allow them to develop better capital to play in the aforementioned field, since when making their investments they generate provisions that allow them to gain better objects at stake and maximize participation in it, in order to improve their skills. Consequently, the field of digital appropriation is inhabited by a set of practices and experiences in which the interests and particularities at stake of the players are put into play. 


\section{Results: between public policy and concrete experiences}

Taking into account what was presented in the previous section regarding the field of digital appropriation, this work privileged those interactions that allow to capture some configurating tensions, which operated as categories and guided the analyzes: the effectiveness of public policy (achievements and shortcomings), rationale and image on public policy (whether appropriate policy or not), concrete experiences and prospective.

\section{a. Tensions before Public Policy in Colombia}

\section{Promises of the information society, skills for work and ICTs in response to inequality}

As it has already been pointed out in the background, public policy discourses referring to a promising future in which ICTs are constituted as resources or tools to achieve development and progress, promote social transformations, overcome poverty and modernize the State and its institutions, including schools, are not exempt from the rhetoric of the Colombian governments between 1998 and 2006. Between 1998 and 2002, during the government of President Pastrana, although the massive use of ICTs was still incipient and Internet connection was something reserved for an elite group of Colombian society, this topic was introduced in the social, economic and educational agenda through two public policy documents: The National Development Plan and the Connectivity Agenda. While in the development plan, telecommunications services are declared as universal access goods, an issue that was resolved by installing community telecommunications access points in most of the country's municipalities, the Connectivity agenda declared the need to integrate Colombia into the global knowledge economy through the ICTs and achieving economic, social and cultural evolution through the massification of the Internet:

With this agenda we are proposing to all sectors of society a long-term state policy that commits the entire nation to the execution of specific actions so that the majority of the Colombian population is linked in a practical and dynamic way to these new creative forces of the knowledge economy. Today, information technologies represent both a unique opportunity and a great challenge for developing countries to make a qualitative leap in our economic, political, social and cultural evolution ... the economy will revolve much more around the use of knowledge than material resources(Pastrana, 2000).

As it can be seen, some justifications are presented as certainties, which fulfill the functions of a true discourse (Foucault, 1969) to incorporate a strategic direction in which Colombia must undertake the ICTs as a device that will transform the economy, which will transit from the production of material goods to the accumulation of capital through knowledge. On the other hand, assuming the place of "developing country", this content presumes that ICTs are a promise that will allow Colombian society to evolve in different areas. These elements are complemented by other contents of the document, such as, benefiting the poor population with ICTs and using these instruments as formulas to modernize the State. Although it is a perspective that will have its effects years later in the educational sector, the Ten-Year Education Plan will validate some of these statements and introduce other guidelines.

This Ten-year plan, which was projected from 2006 to 2016, introduced in its directive six guidelines, the need to adopt a State policy that articulates in the educational system its different levels of initial, basic, secondary, and higher education, the approach of the occupational training for work and human development. Although it contains several dimensions, this approach is based primarily on the introduction of the ICTs at all levels of the educational system, given that its objective is to develop capacities "to learn to learn, learn to be, learn to do, to achieve a comprehensive citizen training, democratic and peaceful coexistence" (Plan Decenal de Educación 2006-2016, p. 48). For this effect, the plan declares as one of its priorities to guarantee the access, 
use and critical appropriation of ICTs as a "tool for learning", so that it allows citizens human development and to participate in the so-called knowledge society. Within its objectives, the document declares:

1. Ensure the incorporation, updating, use and critical and reflective appropriation of ICTs in the training process, by all the actors and at the different levels of the educational system, which also favors the dissemination of knowledge, taking into account the overcoming of economic, regional, ethnic, gender and vulnerability conditions.

2. Promote autonomous and collaborative learnings that develop opportunities and capacities through the critical and thoughtful use of ICTs, closing the digital gap throughout the national territory and enabling active participation in global society. (Plan Decenal de Educación 2006-2016, 2006, pag. 49)

In line with the above mentioned, within the framework of Álvaro Uribe's second term, the 20062010 Education Sectorial Plan was designed. For this government, it was clear that the educational system had to be adapted through different means, including ICTs, in order to form "the human resource required to increase the country's productivity and make it competitive in a global environment" (Ministerio de Educación Nacional, 2008, page 40). This direction also raised the need to adapt the curricula in order to develop skills at all levels of the educational system, especially in secondary education, which should guarantee the development of job skills as a way of articulation with technical and technological programs (Rueda \& Franco, 2018).

\section{Certainties of the ICTs: digital as a market and education dependent on business}

In Law 1341 of 2009 transits from the Ministry of Communications to the Ministry of ICTs; There, it is declared that the priorities of Colombia are the research, provision, promotion and development of these technologies, which involves different sectors of society as a contribution to educational, cultural, economic, social and political development. Likewise, it declares that ICTs will increase productivity, competitiveness, respect for human rights and social inclusion. On the other hand, the document proposes that the State recognizes that access to ICTs, the efficient use of its infrastructure, the development of contents and applications, the protection of users and the training of human talent in these technologies are essential for the consolidation of information and knowledge societies. One of the guidelines that will allow this objective is the articulation of the MinTIC with other sectors, in this case with the educational sector:

Article 39.- Articulation of the ICTs plan: The Ministry of Information and Communications Technologies will coordinate the articulation of the ICT Plan, with the Education Plan and the other sectorial plans, to facilitate the joining of actions, efficiency in the use of resources and move towards the same goals. It will support the Ministry of National Education to: 1. Promote ICT entrepreneurship, from educational establishments, with a high content of innovation 2. Start up a National Digital Literacy System. 3. Train teachers in ICT at all levels. 4. Include the ICT Cathedra within the entire educational system, from childhood. 5. Exercise greater control on Internet cafes for the safety of children (Congreso de la República de Colombia, 2009).

As it can be seen, it is a form of subordination of the educational sector towards the orientations and priorities of an ambivalent sector between the promotion of the right to ICTs and a business model that favors local and transnational private companies. Frequently, the law states that the State will promote free competition between providers, that it will seek to expand service coverage, benefiting vulnerable populations through the provision of communication services, and that respect for free investment will be guaranteed in which it refers to the management of the radio spectrum. On the other hand, although it is established that the providers of telecommunications 
networks and services will be liable for the damages caused to the infrastructure, it is also admitted that they will be guaranteed conditions for the development of the business. For the MinTIC, the priority of the ICTs sector in Colombia is how to turn them into a profitable business, not how they can be potentiated based on training or learning objectives.

These elements are corroborated with the "Live Digital" 2010-2014 and 2014-2018 plans, within the context of the two terms of President Santos. The plans rose within the framework of the strategic management of the MinTIC and constitute the basis for the ICT coverage expansion processes, understood as resources, tools, equipment, software, applications, networks and media, which allow the compilation, processing, storage, transmission of information. For this purpose, the Santos government raised the need to create the appropriate conditions for the ICTs sector to expand its coverage through the deployment of infrastructure, increase broadband penetration, intensify the use and appropriation of ICTs, as well as the generation of contents and applications, around a converging digital ecosystem. To this end, the Live Digital 2010-2014 plan addresses a certainty that seems impossible to refute:

Live Digital is betting on the massification of the Internet, as it has been demonstrated that there is a direct correlation between Internet penetration, the appropriation of Information and Communications Technologies (ICTs), the generation of employment and the reduction of poverty (Ministerio de Tecnologías de la Información y las Comunicaciones , 2014).

As can be seen, on this occasion, the decision makers of this policy again use a real discourse (Foucault, 1969) in which they appeal to the demonstration of a supposed direct relationship between the appropriation of these technologies with the generation of employment and the reduction of poverty. However, it is important to keep in mind that, during this four-year period, $32.7 \%$ of the population was in poverty and the media stated that the country reached an unemployment rate of more than $10 \%$ (Portafolio, 2013). The plan gives priority to the ICTs business model based on the motto: "the market as far as possible, the State as far as necessary". Like the previous plan, the government's directive is to facilitate the conditions for the private sector to be in charge of expanding its infrastructure and services, based on supply, demand and competitiveness rules. In this sense, the Santos government affirms that it is necessary to reduce "tax regulations" so that the private sector can offer the services that are required.

The aforementioned elements have greater visibility in the 2014-2018 live digital plan. On this occasion, the government returns to using the truth of the certainties discourse: there is a "direct correlation between Internet penetration and its usage, the appropriation of the ICTs, the generation of employment, the reduction of poverty and the increase in competitiveness" (Ministerio de Tecnologías de la Información y las Comunicaciones, 2014). For this purpose, this ministry uses the term "numerous studies show" or "there was a clear correlation between ...". As observed, in this version competitiveness is included as an additional element that suggests a direct relationship between the ICTs industry and entrepreneurship models that can become a saving response to high levels of unemployment and poverty.

It is about a policy that prioritizes applications, users, infrastructure and services through a cycle that promotes both the supply and demand for services, especially digital content and Internet and mobile phone services, as a basis for microenterprise development and the "citizens". In this regard, the document indicates that, if the costs of infrastructure and services are reduced, users will be able to pay them "comfortably", and that, by expanding the market, operators would be "motivated" to increase and improve their infrastructure. Consequently, "a virtuous circle is thus generated in which the four components feedback each other positively, generating more infrastructure, more services, more applications and attracting more users" (Ministerio de Tecnologías de la Información y las Comunicaciones, 2014). 
The above is articulated with the 2014-2018 ICT plan by the Ministry of National Education, which focuses its priorities on the construction of regional portfolios based on technological infrastructure, digital educational content, teacher training, school support, the implementation of observatories and the development of monitoring and control actions. The document also addresses the certainties, in this case, related to the alleged correlation between the use of ICTs in students and their better performance on the 'Saber' tests and the reduction in the dropout and repetition rate:

There is an improvement of almost 20 points on average with the use of ICTs in the 'SABER' (intentional) tests. The average is from 286 to 304 (urban official) and from 256 to 268 in rural (...) Percentage of 1 -hour daily use of digital content (...) Reduction of $3.8 \%$ of desertion, reduction of $4.2 \%$ of repetition and improvement of $10.6 \%$ on the relative ranking of the institution. A school goes from position 544 to 492 in Saber $11^{\text {th }}$ grade tests (1 the most, and 1000 the worst) (Lugo C., 2014).

Thus, the document justifies actions based on a truth discourse, since it does not only talks of generalities in which the ICTs favor teaching and make it possible for students to be more interested in the topics of the classes. In this case, the State declares that there is a direct relationship between the use of ICTs (an interval of one hour per day is suggested) with considerable improvements in the performance of a standardized test and the decrease in the dropout and repetition rates. These statements by the high government contrast with data from 2018, which indicates that one in five students in Colombia does not continue studying after grade school, that $12 \%$ is left out in basic secondary school and that only 48 out of 100 young people from rural areas of the country complete secondary education (Vargas, 2017).

In line with the above, the 2016-2026 Ten-Year Education Plan was enacted around 2016. Within the framework of its strategic challenges, the plan stated in its numeral 6 the need to promote the use of "pertinent, pedagogical and generalized" digital technologies to support teaching, construction of knowledge, learning, research and innovation. Likewise, the plan established that it is necessary to advance in the appropriation and use of ICTs, in "differentiated itineraries" for the training of teachers and directors - teachers from all over the country, since it is necessary to transform educational practices.

The mentioned plan maintains interest in implementing initiatives that promote the use of ICTs as pedagogical tools to teach school knowledge. However, its emphasis is on the production of content that favors the adaptation of training curricula at the different levels of education to the "digital society" and the "digital economy". And, instead of addressing digital in curricular content with an aim to training students, the plan presents a list of aspects that are framed within the duties of users who buy and sell in the computer market. On the other hand, the plan manifests the need to make rational use of the ICTs to favor transformative pedagogical practices that positively impact on students learning. And, in line with the above, it proposes as a priority the development of communications skills in students, through the use and critical appropriation of technologies.

Lastly, the MinTIC 2019-2022 strategic plan, developed within the framework of the government of president Iván Duque, sets out as a fundamental challenge to close the digital geographic gap since " $62 \%$ of the population lives in places where Television, Internet and Telephony penetration is less than 20\%" and close the urban digital gap" (Ministerio de Tecnologías de la Información y las Comunicaciones, 2019). The interest in closing these gaps, according to this government, is based on the need to include people from low socioeconomic strata in the purchase of internet, mobile phone and cable TV subscription services, within the framework of benefits of "the digital economy" to the entire population. Likewise, the government raises the need to strengthen the "digital government" to achieve a total digitization of State procedures.

Accordingly, with the foregoing, it can be affirmed that the Duque government's rhetoric regarding digital maintains the same elements of the previous government. Nonetheless, in this case the 
narrative of the digital economy is more conclusive, since it is not only about benefiting the poor but that they have economic resources so that they can acquire computers, applications and internet services. On the other hand, the importance of the ICTs in the configuration of the intangible (digital) economy continues to be proposed, which will allow the country to achieve high standards of development within the framework of the so-called creative industries, which according to president Duque, make part of the orange economy. Finally, it continues to be assumed that ICTs will allow the transformation of the state bureaucracy and institutional efficiency.

\section{b. Tensions in concrete experiences.}

\section{The empty discourse of public policies for the implementation of ICTs in schools}

As mentioned in previous sections, in terms of social and educational policy there is usually an important distance between the intentions of the discourses, including their promises, and the way in which they are carried out in practice. In this case, several participants coincide in highlighting the gaps, contradictions and problems that underlie this divorce between what is said and what is done. One of the most recurring aspects in the interviews is related to the homogeneous, unifying and decontextualized nature of the policies for the implementation of ICTs in schools, especially in view of the needs of educational institutions located in isolated regions, with structural lags as a consequence of state abandonment, as well as the impacts of the armed conflict and the particularities related to the territory, the ethnic groups that inhabit it and the cultural practices that constitute them as communities. The interviews also indicate that there is another important distance between the discourses of politics and the lack of support for teachers in the implementation of ICTs in school spaces. Accordingly, to various testimonies, the State delivers equipment, assigns the responsible teachers and leaves them to their own in school spaces with many problems. Lastly, they also refer to the lack of coordination between State entities that deal with the same subject, in this case, the Ministry of Education, the Ministry of ICTs and the Ministry of Culture. Let's see:

One of the main problems has been assuming the various contexts homogeneously. It has taken an understanding of the social, political, economic and cultural reality of the country in order to respond to real problems (Trainer of trainers, Normal Superior School, Catatumbo).

There has been a massive distribution of tablets and computers in Colombia, but they have been sent without determining the conditions of the school ... many teachers who receive them have no idea how to use them and then put them away (Expert organization promoting teacher recognition).

There has been a lack of understanding the context. I say this because for three years I worked in the "Computers to Educate" program, coordinating the pedagogical area. And a shortcoming is that, when designing the technology appropriation strategy, we designed ("something that is my fault") those strategies from a desk in Bogotá. It was a "single recipe" that was implemented throughout the country. The strategy for Bogotá was the same strategy for Guainía, Vaupés or Chocó (Coordinator of the ICT innovation area, Secretariat of Education of Bogotá and former pedagogical coordinator of the "Computers to Educate" program, by the MEN).

It seems that the State understands the importance of the use of new technologies in education, especially in the rural field, in the municipal capitals, but it remains in a discourse, a vain discourse, a political, transitory, ephemeral discourse, which does not 
manage to permeate really to the bases (...) there is not even an infrastructure, there is not even an electric power to ensure that we can reach these places with new technologies "(Dean of the Faculty of Education, border area).

As it can be seen, for these participants the problem is not only in the equipment or technological provisioning. In the first place, from their experiences the existence of a divorce between the political directions and the needs of the school context is evident. Often, the participants affirm that these are standardized and parameterized strategies that do not adapt to the needs of the educational institution, so that teachers end up adapting the plan of studies curriculum to the conditions imposed by those who design public policy from Bogotá. Secondly, according to the experiences of some participants, the prevalence of an urban-centric approach to ICTs implementation policies in school is evident. Often rural schools in Colombia do not have adequate infrastructure, electricity, drinking water, and much less educational resources to advance in the training processes. Although, this situation is a historical debt of the Colombian governments to rural education, it is striking that, over the past twenty years, with the presence of these policies these problems have not been resolved, yet.

This situation is complemented by the statements made by various participants: the centralizing and homogenizing nature of these policies. Accordingly to what was stated by the former official from the Ministry of Education of the "Computers to Educate" program, and now an official of the Secretary of Education in the area of innovation, it is clear that the implementation strategies of the ICTs have so far not taken into account the social, cultural and territorial characteristics of the communities. As the participant well points out, the strategies that were designed for capital cities ended up being replicated in rural areas, in many cases with a significant presence of indigenous or Afro-descendant populations. For this reason, given that "the same recipe" is applied throughout the country, and since basic instruction on the operation of the equipment prevails, the possibility of carrying out innovation processes from the territories, until now is a postponed aspiration.

\section{The prevalence of the instrumental approach and the lack of teacher training}

Instrumental approaches are those that emphasize provisioning and connectivity, in the training of teachers in technical aspects of the use of devices, and in the development of conventional educational practices that can eventually be "supported" by these technologies. Although the policy usually declares the importance of the critical appropriation of these technologies, the truth is that the programs and strategies that emerge from these policies design standardized training plans, as already discussed, that do not question the meaning of educational practices, not they seek to rethink teaching processes based on the reconfiguration of thinking modes and structuring of knowledge within the context not only of the ICTs but of digital culture, processes of sociotechnical-cultural convergence and connectivism. Let's see:

Nonetheless, despite the large investment in programs such as "Computers to Educate", which focus is on staffing and training in official schools, not enough progress has been made in training teachers in the pedagogical use of ICTs tools (Director and field professional from secretariats of education, Putumayo, Chocó and Bogotá).

Investigating, I have discovered that many teachers in the public sector in Colombia have been certified with a diploma in Education and technology and have been presented with tables and PCs but they have not been trained to use Technology in the classroom (Trainer of trainers, Normal Superior School, Catatumbo).

The greatest flaw is in the instrumental approach and teacher training. The courses offered by the Ministry of Education since 2010 have been focused on the technical component of 
this type of technology, but it has not addressed the pedagogical and didactic dimension of these technologies. Technologies exist, but the use is basic and merely instrumental (Researcher, consultant and university professor in ICTs Teaching and Technology in Education, Bogotá).

In the testimonies of the participants, several critical issues arise regarding the policies of ICT implementation in the school. On the one hand, with some exceptions, it seems that programs such as Computers to Educate and Live Digital have not been able to influence on the modification of teachers' educational practices, much less the development of innovation processes with ICT at school, given the instrumental emphasis of the training and accompaniment processes of the operators hired by the State for this purpose. On the other hand, it is evident that many teachers were trained in banking pedagogies, in which the transmission of information, monolingualism and media singleness prevail. In this sense, the technical training processes do not question conventional practices or open new ways to rethink the domains of school knowledge that are taught, or the mediations and didactics that must be configured to achieve processes of learning or meaning in students.

\section{Conclusions}

Based on the analyzes of this work, it is evident that the policy formulation in Colombia related to digital appropriation, during the period analyzed, has focused on the instrumental approach, which assumes the technological provisioning (equipment and connectivity) as a central topic to the implementation of the policy and development of competences of information and communication technologies; this can be largely explained by Colombia's efforts to become part of the OECD, by adjusting its internal policies to the requirements of this organization, such as the trends and challenges imposed on the countries of the region.

Three major narratives are highlighted in the policy documents analyzed. In the first, governments permanently resort to the rhetoric of global geopolitical, economic, communications and technological changes as a condition that forces society to introduce computers and connectivity in schools so as not to be left behind. Likewise, they frequently resort to the emergence of the information and knowledge society, as well as a model of accumulating capital that transitions from material work to intangible work (Lazzarato, 2006), which, according to Escobar (2005), it constitutes a Manichean mechanism that places structurally disadvantaged countries in a position of subordination vis-à-vis countries that produce this type of technology, while incorporating them into structural adjustment measures related to reforms in work, health, education and social welfare established by multilateral organizations.

The second narrative associates the ICTs with the focus on human capital, which is understood as a mechanism that assumes people as a resource for business or corporate production, attending to the quality of their training and their permanent qualification through the development of skills (Becker, 2009). In this case, ICTs are instruments that, from the initial levels of preschool and basic education, contribute to developing a series of ICT competences that, later on, will allow students to enter the labor market. Work that in the case of Colombia has precarious conditions, especially for young people, given the phenomena of labor outsourcing, work for the provision of services and labor informality imposed by the neoliberal model.

The third narrative, which promises to use ICTs as a tool that contributes to overcoming poverty, reducing social, economic and cultural gaps, as well as opening new fields for work and business (between 2009 and 2019), operates as a Salvationist rhetoric that seeks to magnify this type of technology and use it opportunistically in order to show responses on the public stage to structural 
problems of inequality and exclusion, historically installed in Colombian society. In addition to being one of the promises most used by governments to avoid the implementation of fundamental reforms that overcome inequality, ICTs become a popular route that pleases all social classes and that avoids conflicts with privileged sectors that are not willing to give up power. Lastly, according to the report on ICT Policies in Latin American education systems (2014), in technological infrastructure policies "there are elections based on supply that do not meet the real demand, which generates unnecessary expenses and wrong or temporary policies, a situation that reveals the predominance of market interests "(pág. 109).

The documentary review also allows us to conclude that, over the period, three important transits were arranged: the transition from the provision of computers and Internet in schools to the configuration of a set of services that broadens the general notion of ICTs and that it makes more complex the uses and appropriations of these technologies for pedagogical purposes; the transition from education as an autonomous sector in terms of ICT implementation at school to a strategic matter subordinated to the Ministry of ICTs, which form of operation is the business model; and the transit of beneficiaries to consumers capable of acquiring Internet services, within the framework of the so-called digital ecosystem.

In addition to replacing rights with services, this last approach assumes that the citizen is above all a consumer who can improve their living conditions through their effort and participation in the digital society. On the other hand, it is a policy that substantially modifies the meanings of citizenship and the public. According to Serrano (Serrano, 2005), citizenship is no longer assumed as a project of society in which people are capable of transforming their reality and construe other possibilities for their future, but as a way of individualizing the provision of services to beneficiaries. Likewise, the public ends up reduced to the conformation of a social market, driven by the logic of the private market.

In the second part of the results, the interviews reveal that the appropriation of policy seems not to have had sufficient force in the concrete practices of the various actors. Even though it is recognized that there have been important advances in connectivity and technological provisioning, the equipment is not always of the best quality, an issue that affects school practices. In addition to the above, it is perceived that there is an absence of knowledge of the territory, especially by NGOs or universities that come to the territory pretending to implement public policy, but violating the particularities of those who are there; in this way, the so-called operators -organizations that try to bring public policy to the territory- have a great responsibility in the perception of appropriation failure of government proposals. Along these same lines, the climate of mistrust is strengthened due to the perception of corruption that surrounds these ICT projects, where resources do not seem to reach educational institutions; but also, the difficulties where the armed groups operate, which especially see connectivity as a threat to their actions.

On the other hand, even though many teachers have developed significant experiences of ICT appropriation that manage to overcome the instrumental, these are usually particular cases that, like localized heroism, overcome the limitations of the context; experiences that must be systematized, replicated and socialized, as has occasionally been done with some of them. In this same perspective, larger significant collective initiatives do not appear to be so clearly, and there is also still resistance from many teachers to innovate in their practices, through ICTs or due to directors for fear of damaging computers and have a process for embezzlement of public funds initiated against them, save the equipment or leave it with restricted use.

As it can be seen from the testimonies, the training of teachers must be focused on the appropriation of the ICTs for training purposes. This implies working in opening processes for teachers to modify the forms of teaching that have validated their work for a long time. On the other hand, one of the participants refers to the implementation of teacher training processes focused on the use and appropriation of ICT for pedagogical innovation and the development of 
digital skills. This implies not only instructing teachers but generating collective processes based on their pedagogical experience. It implies the generation of spaces for meeting, deliberation, reflection and decision-making based on their practical knowledge (Carr, 2004) (Barragán, 2015, 2016), as well as the possibility of systematizing their practices, both in difficulties and in successes, and in this way to make sense of improvement and possible innovation actions.

All these elements make it possible to advance in the configuration of the field of digital appropriation in education, which as a construct "calls for a new land and people that does not yet exist" (Deleuze \& Guattari, 1991, p. 110). For this work, then, the manifested interests in public policy do not seem to coincide with the set of practices of the specific individuals, since the dispositions (habitus), the objects at stake, the investments and the capital differ from that promised in Government documents, especially because, as it has been said, the problems that appeared in this study, refer to thinking about the meaning of digital culture, beyond the instrumental use that has been promoted in public policy; because to appropriate it, the transformation of practices is necessary, beyond the promotion of the competences of information and communications technologies. Therefore, there is no evidence of appropriation in the sense that we have outlined above.

\section{References}

Agencia Española de Cooperación Internacional para el Desarrollo. (2011). Experiencias 1 a 1 en América Latina. Seminario Internacional Experiencias 1 a 1 Nacionales. Buenos Aires: Red Latinoamericana de Portales Educativos, RELPE.

Amador-Baquiro, J. C. (2018). Educación interactiva a través de narrativas transmedia: posibilidades en la escuela. Magis, Revista Internacional de Investigación en Educación, 10(18), 77-94. doi:10.11144/Javeriana.m10-21.eint

Barragán, D. (2013). Cibercultura y prácticas de los profesores. Entre hermenéutica y educación. Bogotá: Universidad de La Salle.

Barragán, D. (2015). El saber práctico, Phrónesis. Hermenéutica del quehacer del profesor. Bogotá: Universidad de La Salle.

Barragán, D. (2016). Cartografía social pedagógica: entre teoría y metodología. Revista Colombiana De Educación, (70), 247- 285. doi: https://doi.org/10.17227/01203916.70rce247.285

Barragán, D., Martínez, J., \& Quiroga, L. (2018). El Campo Hermenéutico para el Desarrollo (CHD): Sobre el vulnerable como un « otro». Revista Internacional de Cooperación y Desarrollo, V(2), 196-210. doi:https://doi.org/10.21500/23825014.3921

Bauman, Z. (2000). Liquid Modernity. Polity Press: Cambridge.

Bauman, Z. (2016). Strangers at Our Door. Cambridge: Polity Press.

Becker, G. (2009). Human capital: A Theoretical and Empirical Analysis, with Special Reference to Education. Chicago: The University of Chicago Press.

Bourdieu, P. (1980). Le sens pratique. Buenos Aires: Les éditions de minuit.

Bourdieu, P. (2002). Questions de sociologie. Paris: Les éditons de minuit.

Calvo, M. (2018). Filosofía para la era digital. España: Almuzara.

Carr, W. (2004). Philosophy and Education. Journal of Philosophy of Education, 38(1), 56-73.

Castells, M. (2000; 2003; 2006). La era de la información. Barcelona: Alianza.

Cedefop. (2014). Terminology of European education. A selection of 130 key terms. Luxenbourg: Office of the european union. 
Chacaltana, J., Dema, G., \& Ruiz, C. (2018). El futuro del trabajo que queremos. La voz de los jóvenes y diferentes miradas desde América Latina y el Caribe. Perfiles Educativos, XL(159), 194-210.

Congreso de la República de Colombia. (1992). Ley 30 de 1992 por la cual se organiza el servicio público de la Educación Superior. Retrieved from: https://www.cna.gov.co/1741/articles-186370_ley_3092.pdf

Congreso de la República de Colombia. (1994). Ley 115 de 1994 por la cual se expide la ley general de educación. Retrieved from: https://www.mineducacion.gov.co/1621/articles-85906_archivo_pdf.pdf

Congreso de la República de Colombia. (2009). Ley 1341 de 2009 por la cual se definen principios y conceptos sobre la sociedad de la información y la organización de las tecnologías de la información y las comunicaciones - TIC-, se crea la Agencia Nacional de Espectro y se dictan otras disposiciones. Retrieved from: https://mintic.gov.co/portal/604/articles-8580_PDF_Ley_1341.pdf

Creswell, J. (1997). Qualitative inquiry and research design: choosing among five traditions. California: Sage Publications.

De Certeau, M. (2007). La invención de lo cotidiano. 1. Artes de hacer. México: Universidad Iberoamericana. .

Deleuze, G., \& Guattari, F. (1991). Qu'est-ce que la philosophie? Paris: Les éditions de minuit.

DfES . (2003). Fulfilling the Potential: Transforming teaching and learning through ICT in schools . London: Department for Education and Skills.

Domingo, A., \& Doménech, R. (2018). El futuro del trabajo: una visión general. Teoría y derecho: revista de pensamiento jurídico(23), 16-43.

Doueihi, M. (2008). La grande conversion numerique. Paris: Seuil.

Doueihi, M. (2011a). Digital Cultures. Cambridge: Harvard University Press.

Doueihi, M. (October-december 2011b). Digital humanism? The unesco courier, 32-33.

Escobar, A. r. (2005). Más allá del tercer mundo. Globalización y diferencia. Bogotá: ICANH - Universidad del Cauca. .

EUN. (2007). European Schoolnet Corporate Portal: This is European Schoolnet. Retrieved from: http://www.europeanschoolnet.org/ww/en/pub/eun/about/euninfo.htm

European Commission . (2006). Benchmarking Access and Use of ICT in European Schools 2006. Final Report from Head Teacher and Classrooms Teacher Survey in 27 European Countries. Bonn : European Commission.

Foucault, M. (1969). L'Archéologie du savoir. Paris: Gallimard.

Gadamer, H.-G. (1986). Hermeneutik II: Wahrheit und Methode: Erganzungen, Register. Tübinguen: Mohr.

Galeano, M. E. (2009). Estrategias de investigación social cualitativa. El giro de la mirada. Medellín: La Carreta.

Hagel, J., Schwartz, Jeff, \& Bersin, J. (2017). "Navigating the future of work: Can we point business, workers, and social institutions in the same direction? Deloitte(21), 26-45.

Han, B.-C. (2015). Die Errettung des Schönen. Frankfurt : Fischer Verlag Gmbh.

Han, B.-C. (2016). Die Austreibung des Anderen: Gesellschaft, Wahrnehmung und Kommunikation heute. Frankfurt : Fischer Wissenschaft.

Hepp, P. (2003). Enlaces: el programa de informática educativa de la reforma educacional chilena. In C. Cox (Ed.), Políticas educacionales en el cambio de siglo. La reforma del sistema escolar en Chile. Santiago de Chile: Editorial universitaria.

Hernández, O., Jurado, H., \& Romero, Y. (2014). Análisis de publicaciones hispanoamericanas sobre TIC en escuelas y zonas rurales. Revista colombiana de eduación(66), 105-128.

Hottois, G. (2013, July-December). Humanismo, Transhumanismo, Posthumanismo. Revista Colombiana de Bioética, VIII(2), 167-192.

Hottois, G. ( 2015, July-December). Rostros del trans/posthumanismo a la luz de la pregunta por el humanismo. Revista colombiana de bioética, XX(2), 175-192. 
Huberman, M., \& Miles, M. (1991). Analyse des donnés qualitatives. Bruxelles: De Boeeck.

Ibáñez, J. (Ed.). (2017). La era de la posverdad. Barcelona: Calambur.

International Labour Office. (2019). Work for a brighter future - Global Commission on the Future of Work. Geneva: International Labour Office.

Jara, I. (2014). Las políticas de tecnología para escuelas en América Latina y el mundo: visiones y lecciones. Cepal. Quito: Cepal.

Jenkyns, H. (2006). Confronting the challenges of participatory culture: Media education for the 21st century. White Paper. MacArthur Foundation. Retrieved https://www.macfound.org/media/article_pdfs/JENKINS_WHITE_PAPER.PDF

Laclau, E. (2005). La razón populista. Buenos Aires: FCE.

Lazzarato, M. (2006). Por una política menor. acontecimiento y politica en las sociedades de control. Madrid: Traficantes de sueños.

Lévy, P. (1997). La cyberculture. Rapport au Conseil de l'Europe. Paris: Odile Jacob.

Lévy, P. (2011). The semantic sphere 1 : computation, cognition, and information economy. London: ISTE.

Lévy, P. (2019, December 19). La grammaire d'IEML. Le Métalangage de l'Economie de I'Information. doi:10.13140/RG.2.2.11232.33281

Lugo, C. (2014). Plan TIC en educación. Retrieved from: https://www.mineducacion.gov.co/1759/articles356180_recurso_3.pdf

Lugo, T., López, N., Toranzanos, L., \& Corbetta, S. (2014). Informe sobre tendencias sociales y educativas en América Latina 2014. Políticas tic en los sistemas educativos de América Latina. Buenos Aires: oei, Siteal.

Luna, D. (2018). Rompiendo Límites. Cómo transformamos la vida de los colombianos a través de las TIC. Bogotá: Fundación Amor por Bogotá.

McMillan, K., Honey, M., \& Mandinac, E. (2003). A retrospective on Twenty Years of Education Technology Policy,. Washington: US Department of Education, Office of Educational Technology.

Merkel, A. (2018, May 15). Rede von Bundeskanzlerin Merkel beim 21. Ordentlichen DGBBundeskongress. Retrieved from: https://www.bundesregierung.de/breg-de/aktuelles/rede-von-bundeskanzlerinmerkel-beim-21-ordentlichen-dgb-bundeskongress-am-15-mai-2018-in-berlin-1008658

Ministerio de Comunicaciones. (2008). Plan Nacional de Tecnologías de la Información y las Comunicaciones. Retrieved from: 8247_pe_plan_tic_colombia_2009_2018.pdf https://www.mintic.gov.co/portal/604/articles-

Ministerio de Comunicaciones DNP: UNIFE-DITE. (2000). Agenda de conectividad. Documento Conpes No 3072. Retrieved from: https://www.mintic.gov.co/portal/604/articles-3498_documento.pdf

Ministerio de Educación Nacional. (2008). Plan Sectorial de Educación 2006-2010. Retrieved from: https://www.mineducacion.gov.co/1621/articles-230696_archivo_pdf_revedu_plan_sectorial.pdf

Ministerio de Educación Nacional. (2018). Sistema educativo colombiano. Retrieved from: https://www.mineducacion.gov.co/portal/Preescolar-basica-y-media/Sistema-de-educacion-basica-ymedia/233839:Sistema-educativo-colombiano

Ministerio de Tecnologías de la Información y las Comunicaciones. (2010). Plan vive digital 2010-2014. Retrieved from: https://www.mintic.gov.co/portal/604/articles-5193_recurso_2.pdf

Ministerio de Tecnologías de la Información y las Comunicaciones. (2014). Plan vive digital 2014-2018. Retrieved from: https://www.mintic.gov.co/portal/604/articles-5193_recurso_2.pdf

Ministerio de Tecnologías de la Información y las Comunicaciones. (2019). Plan estratégico min tic 2019-2022. Versión Borrador. Retrieved from: https://www.mintic.gov.co/portal/604/articles82084_plan_estrategico_institucional_mintic_2019_2022.pdf 
OECD - Organization for Economic Cooperation and Development. (2005). Are Students Ready for a Technology-Rich World?: What PISA Studies Tell Us. Paris: OECD.

OECD - Organization for Economic Cooperation and Development. (2016). Educación en Colombia. Aspectos destacados. 2016. Paris: OECD.

OECD - Organization for Economic Cooperation and Development. (2017). Estudios económicos de la OECD. Bogotá: OECD.

OECD - Organization for Economic Cooperation and Development. (2019). Estudios de la OECD sobre Transformación Digital. "Going Digital" en Colombia". Resumen Ejecutivo. Retrieved from: http://www.oecd.org/going-digital/going-digital-en-colombia-resumen-ejecutivo.pdf

Pastrana, A. (2000, July 14). Agenda de Conectividad: Colombia conectada con el futuro [Discurso del presidente Andrés Pastrana]. Retrieved from: https://andrespastrana.org/agenda-de-conectividadcolombia-conectada-con-el-futuro/

Plan Decenal de Educación 1996-2005. (1996). Plan Decenal de Educación . Retrieved from: https://www.mineducacion.gov.co/1621/articles-85242_archivo_pdf.pdf

Plan Decenal de Educación 2006-2016. (2006). Plan Decenal de Educación 2006-2016. Retrieved from: http://www.plandecenal.edu.co/cms/media/herramientas/pnde_2006_2016_compendio.pdf

Plan Decenal de Educación 2016-2026. (2016). Plan decenal. Retrieved from: http://www.plandecenal.edu.co/cms/media/herramientas/PNDE\%20FINAL_ISBN\%20web.pdf

Portafolio, D. (2013, January 31). Desempleo en Colombia durante el 2012 fue de 10,4\%. Retrieved from: https://www.portafolio.co/economia/finanzas/desempleo-colombia-2012-10-74638

Quartiero, E., Bonilla, M., \& Fantin, M. (2012). Políticas para la inclusión de las TIC en las escuelas públicas brasileñas: contexto y programas. Campus Virtuales. Revista Científica de Tecnología Educativa, I(1), 115-126.

Quiroga, M. (2008). Análisis Comparado de Experiencias de Introducción de las TIC en el Aula. El Rol del Coordinador Tecnológico y su Impacto en el Éxito de las Políticas Pública. Revista Iberoamericana sobre Calidad, Eficacia y Cambio en Educación, VIII(4), 149-164.

Redal. (2005). Informe Científico Final: Redes Escolares de América Latina, Una investigación sobre las mejores prácticas. Retrieved from: https://idl-bnc-idrc.dspacedirect.org/handle/10625/30591

Relpe. (2004). Declaración de Santiago, Acuerdo de Cooperación Regional en Políticas de Informática Educativa y Acta de Constitución de la Red Latinoamericana de Portales Educativos. Santiago de Chile.

Rueda, R., \& Franco, M. (2018). Políticas educativas de tic en Colombia: entre la inclusión digital y formas de resistencia-transformación social. Pedagogía y Saberes(48), 9-25.

Scolari, C. (2018). Las leyes de la interfaz: diseño, ecologia, evolucion, tecnologia. Barcelona: Gedisa.

Serrano, C. (2005). La política social en la globalización. Programas de protección en América Latina. Santiago De Chile: Naciones Unidas.

UNESCO. (2002). Technologies for Education: Potentials, Parameters and Prospect. Paris: UNESCO.

UNESCO. (2014b). Teaching and learning: achieving quality for all; EFA global monitoring report, 2013-2014. Paris: UNESCO.

UNESCO. (2016). Education for people and planet: creating sustainable futures for all, Global education monitoring report, 2016. Paris: UNESCO.

UNESCO. (2017). Accountability in education: meeting our commitments; Global education monitoring report, 2017/8. Paris: UNESCO.

UNESCO. (2019). Global education monitoring report, 2019: Migration, displacement and education: building bridges, not walls. Paris: UNESCO.

Van Dijck, J. (2013). Culture of Connectivity: A Critical History of Social Media. Oxford: Oxford University Press. 
Vargas, R. (2017, May 27). Deserción y decepción. Retrieved from: https://www.semana.com/opinion/articulo/desercion-escolar-en-colombia/526304

World Bank. (2006). Information and Communication for Development: Global Trends and Policies. Washington: World Bank. .

World Bank. (2019). World Development Report 2019: the changing nature of work. Washington: World Bank. 